\title{
He Who Appoints the Piper: Understanding Reasons and Implications of Agency Management "Politicisation" in Slovakia
}

\author{
Miroslav Beblavy, Emilia Sicakova-Beblava, Darina Ondrusova
}

\section{Summary/Abstract}

Discussion of politico-administrative relations as well as the research on agencies generally treats the "politicisation" of agency management as a single, "black-box" concept, according to which agency managements (and other senior civil servants) are either political or not. Our paper shows that, using a strict, but widely applied definition of what constitutes a political appointment, agency heads in Slovakia are overwhelmingly "political", but that the implications of politicisation vary, depending on the type of politicisation. In particular, we distinguish personal nominations of the responsible minister and contrast them with party nominations based on coalition agreements. Based on a series of interviews with senior policy-makers on both sides of the politico-administrative divide, we show that the selection mechanism, incentive structure and robustness of actual accountability mechanisms differs more between these two types of politicisations than between the ministerial and formally "non-political" appointment.

\section{Introduction}

Slovakia, similarly to other states in Central and Eastern Europe, has passed through a significant transformation of its public sector in the past two decades. Currently the Slovak public sector consists of several layers including the core state administration and the state agencies. Although the civil-service reform has been conducted in Slovakia (with some backsliding - see e.g. Randma-Liiv and Järvalt 2011; Beblavý 2009; Malíková 2006), the recruitment processes in the state agencies are only partially touched by the Civil Service Act and usually are covered by distictive rules. 
The politicians have several tools to control the state agencies, and one of them is through personnel policy and recruitment systems of the senior management. Therefore it is not surprising that the politico-administrative relations are studied not only within the core state administration - civil service - but also in the state agencies.

The usual approach in studying politico-administrative relations in public institution is to distinguish between applying administrative doctrine (formally "nonpolitical" appointment) vs. political doctrine in recruitment policy, and for personnel decisions made by politicians the general term politicisation is used. However, this approach does not show who the concrete political decision-maker is and what related incentives as well as implications of the given decisions are.

In this paper we therefore look at the particular types of politicisation in the recruitment system of the senior management in the Slovak state agencies and distinguish personal nominations of the responsible minister from party nominations based on coalition agreements. We contrast the legal state of politicisation (how many appointments can de iure be made by politicians in Slovak state agencies) and the real state (what is the influence of politicians in recruiting senior management in the agencies, and does it differ according to an individual or a collective decisionmaker (see below)).

The paper consists of 4 parts. It starts with an overview of literature on the politicisation of public administration and its forms. Here we will present three classifications of politicisation, focusing on the legality of the appointment, selection criteria for an appointment, and the type of decision-maker. In the second part, the methodology is provided. Our research was conducted in two stages. The first one was based on the analysis of legal acts and related to the legal state of politicisation. The second one consisted of a series of interviews and was related to the actual state of politicisation. The paper continues with presenting the main findings; among others the paper shows that instead of a dichotomy - distinguishing only between ministers or the government as political bodies that nominate the senior management level at the agencies -, the real Slovak political world works with a trichotomy also including the coalition council. Finally, in the last part, the main conclusions are drawn.

\section{Typology of politicisation}

On the following pages we focus on the definition of basic theoretical concepts associated with the issue of politico-administrative relations and in particular the process of recruitment into the public sector as discussed by the researchers.

In the aftermath of every election the politicians start to exercise the powers vested to them, generally having the ambition to fulfil the promises made to voters in the campaign. To achieve this goal they can turn to the state administration in- 
cluding the public agencies. Naturally, there are many definitions of agencies. Here, we refer to agencies as legally distinct state-budgetary organisations which are autonomous from ministries (although sometimes formally subordinated to them) and implement core state functions (regulation, collection of taxes and other state revenue, enforcement of laws) rather than deliver services. ${ }^{1}$ In other words, our focus is on institutions delivering core state functions, but usually not performing a policy-making functions, which is the province of ministries.

The personnel make-up of these institutions is not always in accordance with the expectations of either of the actors with respect to which people to include in the team managing the individual departments. Thus, Aberbach, Putnam and Rockman defined the relations between politicians and the civil service as an uneasy partnership in charge of the modern state (Aberbach et al. 1981). The uneasy partnership between the given actors is driven by different expectations with regard to the types of activities performed by actors, as well as their quality, by which we mean their knowledge capacity, willingness to take action, enthusiasm for change or innovations, including the expectations of loyalty of different sorts. In this paper we focus only on one specific aspect of these relations, namely the relation of political elites towards the civil servants. More specifically, we focus on the application of the so-called doctrine of political rationality in recruiting agency top representatives as described above. This approach is called politicisation in the broader sense of the word, since politicisation is a term that is used to describe different processes in a society. It is associated with a (change in the) number of (party) political nominations, (party) political loyalty of the civil servants, as well as the political sensitivity of the bureaucracy (Van der Meer et al 2007).

Similarly Peters defines politicisation as the substitution of the merit principle in the recruitment process by the system of promotion, reward and obedience of the civil servants according to the political criteria (Peters 2010). As already stated, this is quite a broad definition and in this paper, we only use the term as defined by Gregory (2004), who sees politicisation as "the capacity for the political executive to exercise authority directly in the appointment of top governmental officials."

There are a number of mechanisms with the goal of ensuring top-down politicisation (see for example Van den Meer (2009)), and we more specifically define the individual forms of top-down politicisation in the following text.

The first classification results from the legal perspective. Here we can differentiate between political nominations de iure and de facto (see also Ondrušová and Beblavý 2012). The former is the situation in which a politician has a formalised authority to choose and appoint the members of his/her cabinet, directors of a state agency or advisors. In the latter case there is no legal authorisation for this method

1 For a more specific definition see the methodology part. 
of recruitment, but it happens in practice. An example of this is a manipulation, an informal political nomination to permanent position in the state sector.

Within the de iure framework of legal politicisation we can speak of the socalled structural politicisation. It is a creation of formal legal structures, positions within the organisation that are filled according to the decisions of the political authority, and the appointment of these positions through political nomination of this kind is legal (Rouban 2004). In the case of structural politicisation it is possible to further distinguish which levels of the department are subjected to the structural politicisation. An example can be taken from the appointment of people to the departmental offices, the appointment to the senior positions in the state administration or the managerial posts in the departmental agencies. Another example of structural politicisation is the deconstruction of the lineal bureaucratic hierarchy and the creation of a new institution - QUANGO, which is more likely to be responsive to the orders of the political leadership. A change occurs in terms of the environment within which the decisions are made, and a greater control of the decisions adopted is ensured by the political nomination of the decision-makers. From a principal-agent perspective, elected party politicians (principals) use the power to appoint to ensure that the policies they decide will be implemented without distortions by appointees (agents) which need not be the case of civil servants (Kopecky et al. 2011; Huber and Shipan 2002).

At the same time, due to less media publicity and public pressure, political appointees as key representatives of QUANGOs can also be used as tools of the strengthened political or personal influence of the decision-maker, the personal or party patronage, especially in cases where the core civil service is governed by stricter rules and professional performance is expected (Beblavy 2002). On the one hand, this might seem contrary to the ambition to delegate autonomy, particularly in personnel and financial issues, to independent expert-based agencies. In fact, such autonomy is considered a key feature of the agencies (see e.g. Beblavy 2009; Gill 2002). However, it is still elected politicians who, in the end, are accountable to citizens for governing the public sector, with QUANGOs not taking a part. Therefore, political appointments to these positions instead of complete delegation of power to civil servants need not be surprising. Thus one of the core factors strengthening the existence of the structural politicisation cited in the literature are the legal and/or political difficulties in changing the civil servants who are ignoring the needs of the current political leadership, which is dissatisfied with their performance (Peters and Pierre 2004; Meyer-Sahling 2004, Page and Wright 1999). This can lead to the duplicity of employees, when the cadres chosen by the politicians are complementing the career civil servants.

When talking about top-down politicisation, a second typology can also be used, dividing politicisation into patronage, functional politicisation and formal politicisation. In this typology the criterion is the incentive of the decision-maker 
related to the responsiveness and competence of an appointee. Kaufman (1956) describes bureaucrats as professionals who can ensure stability and continuity in policy-making by means of a merit system and without interference of politicians in the recruitment process. These bureaucrats are competent and neutral in providing their expertise to any political leadership. This approach is known as neutral competence (Kaufman 1956). However, politicians often see bureaucrats as loyal adherents to the previous government (Meyer-Sahling 2004), who are too rigid to adapt to current political and policy ambitions. This is especially obvious in cases when public administration as such is subject to reforms. In that case, bureaucrats can even become an interest group protecting current organisational settings. Due to information asymmetry, they are in a better position compared to the politicians and can easily defend the status quo in organisational terms rather than public interest (Peters 2010). As a result, politicians prefer to appoint new recruits rather than senior officials for some positions. These appointees are experts who share the politicians's views regarding the given agenda. In this context, Svara (2001) uses the term responsive competence. The appointees are experts supporting politicians who usually act as managers seeking to pursue their agenda. In other words, politicians use their right to appoint the nominees to some positions in order to ensure a good implementation of the decisions made by politicians. Finally, pure responsiveness refers to the situation of a politician appointing a person who is not an expert in a given field, but is committed to the politician's preferences. In practice, this can be a situation where an appointee acts as a kind of controller and mediator to the politician rather than the real manager or director of that institution.

Thus, in sum, the process of recruitment by the political leaders to the top management-level positions does not have to involve party patronage or party appointees with no professional qualification. Politicisation, as has been noted above, can also occur with the goal of improving the political compatibility of bureaucrats and politicians in their view of individual policies. Value-sharing does not necessarily mean party affiliation, and its societal legitimacy is higher than in cases of using pure responsiveness, even though this changes with time as suggested by Peters (2004). Therefore, returning to the second typology, the politicisation can have a form of patronage, functional politicisation or formal politicisation.

In the case of personal and party patronage/clientelism, the key factor in the appointment is personal or party loyalty (Bearfield 2009), and the decision-maker chooses it for a number of reasons. An example is the formation and strengthening of party structures, as well as the personal positions of power in the party and the surrounding environment. This system of recruitment by political appointment is typical of developing countries, less so in the older democracies, even though in some of these countries we can observe cases of patronage. Greece would serve as an example in this respect (Van der Meer et al 2007). 
With respect to the functional politicisation, numerous authors cite the political responsibility of politicians who need tools to ensure the fulfilment of duties and want to have greater control over policies as well as the performance outcomes of organisations over which they hold political responsibility. The public tends to view politicians as responsible for the actions taken within their department. Functional politicisation thus comes into existence as a reaction to the problem of control (Peters and Pierre 2004) and as a coordination mechanism. This is why numerous authors (for example Mulgan 1999) divide this type of politicisation into two subtypes, which in practice are often hard to differentiate, namely the policy-oriented politicisation and managerial politicisation. This shows that the recruitment by political leaders to the senior public positions does not have to involve party patronage or party appointees with no professional qualification. Politicisation, as has been noted above, can also occur with the goal of improving the political compatibility of bureaucrats and politicians in their views of individual policies. Value-sharing does not necessarily mean party affiliation.

Formal politicisation is a situation where the appointment is directed by the political decision-maker, but the criteria of the selection are based exclusively on the expertise. The reason for this situation can be the tradition of appointment by the political decision-maker to the particular position and broad societal consensus for a required professionalism in the given senior position.

Finally, although not previously addressed in the literature, we also find it important to classify politicisation according to the type of political decision-maker. Based on this criterion, political decision-makers can be individuals as well as collective organs. Individuals are ministers who are directly responsible for controlling their appointees and at risk of dismissal in case of these appointees's failure. At the same time, and perhaps therefore, it is more likely that they need not consult their choice of appointee with some other subject such as partner coalition parties (which is the case for the government). On the other hand, collective decision-makers are those who appoint a candidate as a result of negotiations between all relevant partners. Namely they are mainly governments. In coalition governments this picture gets much more complicated, and it can be in fact political parties who reserve the right to appoint to top positions. We will deal with this issue in more detail in the methodology part.

The following table provides a summery of the types of politicisation. 
Table 1

Typology of politicisation

\begin{tabular}{|l|l|l|l|}
\hline $\begin{array}{c}\text { Criterion: } \\
\text { motivation of the } \\
\text { selection vs. legal } \\
\text { criterion }\end{array}$ & \multicolumn{1}{|c|}{$\begin{array}{c}\text { Criterion: } \\
\text { responsiveness }\end{array}$} & $\begin{array}{c}\text { Criterion: } \\
\text { responsive } \\
\text { competence }\end{array}$ & $\begin{array}{l}\text { Criterion: neutral } \\
\text { competence }\end{array}$ \\
\hline $\begin{array}{l}\text { Illegal } \\
\text { nominations }\end{array}$ & $\begin{array}{l}\text { Illegal } \\
\text { personal/partisan } \\
\text { patronage/clientelism }\end{array}$ & $\begin{array}{l}\text { Illegal functional } \\
\text { politicisation }\end{array}$ & - \\
\hline Legal nominations & $\begin{array}{l}\text { Legal } \\
\text { personal/partisan } \\
\text { patronage/clientelism }\end{array}$ & $\begin{array}{l}\text { Legal functional } \\
\text { politicisation }\end{array}$ & Formal politicisation \\
\hline
\end{tabular}

Source: Authors

\section{Research methodology}

The Slovak state sector consists of different layers, including the core civil service and state agencies. To better understand politico-administrative relations in the Slovak state agencies we focused on the following questions:

- To what extent is there a structural/de-iure politicisation in the Slovak public agencies?

- What type of politicisation is it - individual or collective politicisation?

- What is the real/de-facto politicisation of the selection of the senior management level in the Slovak state agencies?

- What is the relation between de-iure and de-facto politicisation in the Slovak state agencies?

To answer the first two questions we look at the way the senior management level at agencies has to be selected and who makes that decision as defined by the law. Here the first criterion for determining the type of political function according to the decision-maker is individual and collective decisions.

The Slovak government is an example of a collective body. However, the government is not the only collective body, which has the power to conduct political nominations, and in this group we can also include the parliament. The power to appoint certain positions is also in the hands of the president of the republic. The president seemingly operates as an individual body by himself. However, his nominations cannot be fully compared with the nominations of the minister, especially if the president is elected directly by the people. The difference is that while the minister has a political responsibility for his nominee, and in case of the latter's failure there will be pressure on the minister to resign, there is no such direct responsibility 
for the president. Furthermore, the nominee of the president has no accountability towards the latter as the nominee is not his subordinate.

Therefore the second criterion for determining the type of political function according to the decision-maker is the political responsibility, where the direct political responsibility is in the hands of ministers and the indirect political responsibility in the hands of collective bodies and the president. An overview of the combination of both criteria is offered in the following table.

Table 2

Types of decision-makers by the chosen criteria

\begin{tabular}{|l|c|c|}
\hline \multicolumn{1}{|c|}{ Criterion } & Collective decision-maker & $\begin{array}{c}\text { Individual decision- } \\
\text { maker }\end{array}$ \\
\hline $\begin{array}{l}\text { Direct political } \\
\text { responsibility }\end{array}$ & - & Minister \\
\hline $\begin{array}{l}\text { Indirect political } \\
\text { responsibility }\end{array}$ & Government, parliament & President \\
\hline
\end{tabular}

Source: Authors.

Based on this typology of decision-makers two types of political positions were identified for the purpose of research:

- collective political positions (CPP), which are filled through appointment by the government or parliament;

- ministerial political positions (MPP), which are filled through ministerial appointment by the minister or another individual body which holds direct political as well as substantive responsibility.

We included presidential appointments, somewhat counterintuitively, under collective decision-making. The reasons were twofold. First of all, in practice the presidential appointment in Slovakia is generally a finalisation of a nomination process where the nomination is made by the government or the parlimant. Secondly, even in the very limited number of cases where the president is the sole appointment authority, his indirect political responsibility and lack of accountability for the performance of agencies makes him more akin to collective rather than ministerial nominations in our conceptualisation.

As for the research sample, we looked at the politico-administrative relations in 44 agencies that were established and are regulated by individual law. In other words, they were not set up under a general regulation, but have one of their own. This criterion was applied for two reasons:

- it is a good proxy for the political importance of the agency and its position as a body; 
- it means that the procedures for the appointment and dismissal of senior personnel tend to be individually regulated by the law so that the sample is diverse and reflects a variety of sectoral or even individual factors.

These 44 agencies can be further divided into two groups:

- 17 autonomous regulatory organisations at the central level ${ }^{2}$, and

- 27 organisations subordinated to various Slovak ministries. ${ }^{3}$

The data were collected based on a review of an annual set of laws and their amendments from 1993 to 2011.

To answer the third question we conducted more than 20 interviews with senior policy-makers on both sides of the politico-administrative divide. The sample of interviewees included individuals that were appointed to one or more of the following positions:

- minister,

- state secretary of the ministry,

- advisor to the minister,

- director general of a section (highest level of ministerial administration),

- director of a division (the second highest level of ministerial administration)

- chief executive of a budgetary or contributory organisation.

The optimal interviewee was an individual who held the same or different positions during the numerous governments and for the longest period of time to increase the information yield of the interview and allowed a direct comparison of personal experience. The sample included some prominent and politically active individuals as well as some non-prominent individuals with long-term connections to a particular political party but also some individuals who are neither members of nor associated with any political party. With regards to the nature of the interviewees and the questions they were asked, they were informed that even though the analysis of the findings will include the information and the citations they offered, these will not be associated with the names nor be presented in a way that could allow any identification.

The sample of ministries covered in the research includes the key departments from the point of view of political, fiscal and security weight and at the same time respects their diversity, so that it allows it to uncover the differences between different types of departments. The ministries are:

2 The example of an autonomous organisation at the central level is the Slovak Statistical Office, or the Telecommunications Regulatory Authority of the SR.

3 The example of an organisation subordinated to a ministry is the Civil Aviation Authority of the SR, which is subordinated to the Ministry of Transport, Construction and Regional Development of the SR. There are only two cases when an institution transformed from a subordinated to an autonomous body, one of them being the Telecommunications Authority. However, it is far behind the aims of this paper to discuss these settings in detail. 
- Ministry of Finance;

- Ministry of Education (the name changed in 2010);

- Ministry of Labour, Social Affairs and Family;

- Ministry of Justice;

- Ministry of Interior;

- Ministry of Foreign Affairs.

The interviews were conducted in the months of May-August 2011 and covered the governance of four executives: Dzurinda I, Dzurinda II, Fico, Radičová. All together it covered 13 and a half years. The period of these four governments was chosen because it covers a sufficient diversity of governments and the ruling parties to allow us to make generalised observations.

\section{Main findings}

The research came with 3 main findings. The first finding is related to the way the senior management is selected in the Slovak state agencies. The methods of political vs. formalised selection of the senior staff members in listed institutions as defined in the methodology are shown in Table 3.

\section{Comment:}

The amount of positions that are being filled based on formal selection in 2004 have increased due to the creation of the Public Health Authority of the Slovak Republic and 36 regional offices. According to laws 126/2006 and 355/2007 those positions are being filled by the director or the chief hygienist, after an agreement with the Minister of the Health. This is the cause of the increase in the numbers of ministerial political functions and the decrease in positions that are being filled on the basis of formal selection processes.

The data in the table show that the amount of institutions have nearly doubled since the creation of the Slovak Republic (increase from 26 to 44) and the amount of the positions in the senior management have nearly tripled (from 60 to 163), which is also related with the act of creating branches of these institutions. As for the way the senior management level is selected, the data clearly show that the vast majority of senior management personnel at the selected sample of public agencies (budgetary and contributory organisations) are filled through political processes that imply de-iure structural politicisation of these types of state agencies.

However, as we have showed in the methodology, decision-makers within the political processes may differ, and we distinguished between individual (for example ministerial) politicisation with clear accountability for the nominee and collective (for example governmental) politicisation with less clear political accountability for the nominee. Table 4 provides an overview of the types of politicisation in the given set of public agencies. 
Table 3

Methods of selection of the senior staff members in public organisations, in the years 1993-2011

\begin{tabular}{|l|c|c|c|c|}
\hline Year & $\begin{array}{c}\text { Political } \\
\text { selection }\end{array}$ & $\begin{array}{c}\text { Formalised } \\
\text { selection }\end{array}$ & $\begin{array}{c}\text { Number of } \\
\text { positions }\end{array}$ & $\begin{array}{c}\text { Number of } \\
\text { institutions }\end{array}$ \\
\hline 1993 & 60 & 0 & 60 & 26 \\
\hline 1994 & 60 & 0 & 60 & 26 \\
\hline 1995 & 62 & 0 & 62 & 27 \\
\hline 1996 & 63 & 0 & 63 & 28 \\
\hline 1997 & 63 & 0 & 63 & 28 \\
\hline 1998 & 82 & 0 & 82 & 31 \\
\hline 1999 & 84 & 0 & 84 & 29 \\
\hline 2000 & 84 & 0 & 84 & 29 \\
\hline 2001 & 88 & 0 & 88 & 33 \\
\hline 2002 & 91 & 0 & 91 & 37 \\
\hline 2003 & 106 & 1 & 107 & 41 \\
\hline 2004 & 99 & 52 & 151 & 42 \\
\hline 2005 & 88 & 61 & 149 & 40 \\
\hline 2006 & 136 & 16 & 152 & 42 \\
\hline 2007 & 144 & 16 & 160 & 41 \\
\hline 2008 & 144 & 16 & 160 & 41 \\
\hline 2009 & 145 & 16 & 161 & 42 \\
\hline 2010 & 145 & 17 & 162 & 43 \\
\hline 2011 & 146 & 17 & 163 & 44 \\
\hline
\end{tabular}

Source: authors.

The data in table 4 show that the de-iure politicisation of these public agencies is mainly given to the hands of ministries that would imply clear political accountability to political nominees.

The senior management at the organisations subordinated to ministries is mostly selected by ministers, whereas in the case of autonomous regulatory organisations (such as the Statistical Office) it is mostly a collective decision. It implies that the legal form of selection is related to the type of the state agency.

As for agencies subordinated to ministries, it is also to be noted that the minister is in some cases directly limited by the law when selecting the candidate. There are two types of limitations, sometimes they are combined. Either they revolve around the matter of his current term and previous experiences, or they are based upon the responsibility of the minister to consult in the selection of the candidate. 


\section{Table 4}

Types of politicisation in the given sample of state agencies since 1993 till 2011

\begin{tabular}{|l|c|c|c|c|}
\hline Year & $\begin{array}{c}\text { Collective } \\
\text { political } \\
\text { positions }\end{array}$ & $\begin{array}{c}\text { Positions } \\
\text { decided by } \\
\text { minister }\end{array}$ & $\begin{array}{c}\text { Number of } \\
\text { positions }\end{array}$ & $\begin{array}{c}\text { Number of } \\
\text { institutions }\end{array}$ \\
\hline 1993 & 24 & 36 & 60 & 26 \\
\hline 1994 & 24 & 36 & 60 & 26 \\
\hline 1995 & 26 & 36 & 62 & 27 \\
\hline 1996 & 27 & 36 & 63 & 28 \\
\hline 1997 & 27 & 36 & 63 & 28 \\
\hline 1998 & 27 & 55 & 82 & 31 \\
\hline 1999 & 27 & 57 & 84 & 29 \\
\hline 2000 & 27 & 57 & 84 & 29 \\
\hline 2001 & 29 & 59 & 88 & 33 \\
\hline 2002 & 40 & 51 & 91 & 37 \\
\hline 2003 & 43 & 63 & 107 & 41 \\
\hline 2004 & 43 & 56 & 151 & 42 \\
\hline 2005 & 43 & 45 & 149 & 40 \\
\hline 2006 & 44 & 92 & 152 & 42 \\
\hline 2007 & 52 & 92 & 160 & 41 \\
\hline 2008 & 52 & 92 & 160 & 41 \\
\hline 2009 & 52 & 93 & 161 & 42 \\
\hline 2010 & 52 & 93 & 162 & 43 \\
\hline 2011 & 52 & 94 & 163 & 44 \\
\hline 509 & & & \\
\hline
\end{tabular}

Source: authors

The second finding is related to de-facto politicisation - how the decisions concerning the recruitment of the senior management level are done in reality. From the interviews we can conclude that the personal decision-making about senior management-level positions at the central government level, including state agencies, is divided among three actors:

- minister or state secretary (including possible influences of his party or other in-groups on his decision-making);

- coalitional decision-making, where the positions are allocated to individual parties that are able to make the decision partially or absolutely independently from the minister;

- long-term stability and mostly technocratic personnel decision-making, where the particular position is not filled only de iure, but also de facto on the basis of an apolitical approach, in which neither the minister and nor the political parties interfere. 
Personal decisions of the minister and the state secretary of the ministry mainly concern the head of the ministerial administration and the minister's advisors, and to a certain degree also the directors general of the sections and the CEOs of subordinated organisations (mostly budgetary organisations). Personal decisions are fragmented on the basis of the power structure in the government department. In some places they are concentrated only in the hands of the minister, in other places, this power is dispersed to the state secretary of the ministry and other key personnel (selected advisors, selected directors general ...). An example comes from the Ministry of Education, where the long-time senior executive said that during the Radičová government the following situation occurred: “Today, the Minister is involved only to a small degree in personnel recruitment, and this concerns only the people that are closest to him. From the section below they delegate the authority downwards - delegation of authority in practice." According to a clerk serving under the Dzurinda government operating in the Ministry of Justice this had been the way of doing things: "The Minister had brought his own key people, and then they chose the staff that they needed. Meaning that there had been no single authority that would pick people."

Coalition-based appointments are related mainly to the statutory positions in local state administration and high executive positions in important organisations controlled by the ministry, mainly in the largest companies and key agencies. When speaking of the border between personal and coalition decisions, according to a politician who in the past worked in a leading position of the department: "With respect to the local state administration, national agencies and public companies, we can observe in time a larger, more formal, clearer and rising acceptance of politicisation of the management positions. It does not seem legitimate to parties that the minister should have a veto power in local positions. There is a strong pressure of parties on a particular level and an understanding that local positions are local affair." The same politician explained: "The party has an interest in putting their people in these particular positions for the reasons of patronage, financing of the party, rewards or putting forward their ideology. Costs of this approach for the party are limited, because it receives discontent only partially - also the costs of the incompetence are limited - it hurts the party indirectly, but mainly the minister. Cost-benefit for the party/party members turns out differently from the one for the minister and governmental department. For the minister, the partisan nature of the person is not his main problem, but the incompetence, corruption and the threat that the governmental department will be controlled through partisan nomination by somebody else." Other politician that had taken part in the management of the department agreed: "The party is spread out territorially, and there are many people that are trying to get work in this way. Local overlords are much more aggressive when placing their people into these positions, and this is how it works in each party. You can fight against it only by the power of the minister. When I was in power, people could not get to the department and its main structures in this manner, 
mostly into the regional matters. I saw it as a necessary evil. It was more important to uphold the main structures, to not let anyone in there."

Long-term stability and the technocratic type of decision-making mainly concerns the directors of the divisions and lower executive positions, as well as less important budgetary organisations of the government ministry. In many cases it also affects the general directors of the divisions. These borders are quite fluid and are changing as an effect of the political power of the minister and the type of government department.

One of the possible examples of these differences is the Ministry of Finance under the leadership of Ivan Mikloš and Ján Počiatek. At first, Ivan Mikloš largely filled the key positions of chief executives of the sections and more technocratically oriented agencies (control of debt and liquidity, state treasury) with technocrats according to his personal decisions. This created a space in which Ján Počiatek and, after his return, Ivan Mikloš were not able to change these positions anymore. Thus borders of the technocracy were defined quite broadly at the Ministry of Finance, both vertically and horizontally. The clash of the personal, partisan and coalition principles has been happening and is happening in relation to two key agencies, the tax and the customs directorate. The chief executives of these institutions were appointed largely due to personal decisions of the ministers; local chief executives of the tax and customs directorates were much more of a coalition decision, and the ministers were able to control it only in a limited way.

On the other hand, for example in the Ministry of Education such a stabilisation and de-politicisation has never been successful, and so the positions of the chief executives and statutory organisations have remained mainly a personal decision of the minster, but at the same time the local positions are still subordinate to the coalition agreements. The Ministry of Education is quite an extreme, as we have been able to see above, for which the ministers from the SNS can be held accountable.

A third example is the Ministry of Justice under the leadership of Daniel Lipšic and Štefan Harabin, where in neither case there was a major interference from the side of the coalition, but there was a very strong imprint of the personal decisions of the minister.

These findings are summarised in Scheme 1, which shows stylised findings about the decision-making regarding personnel questions and their placement amongst the three already mentioned decision-making points. 


\section{Scheme 1}

Who actually is in charge of the recruitment to the significant positions

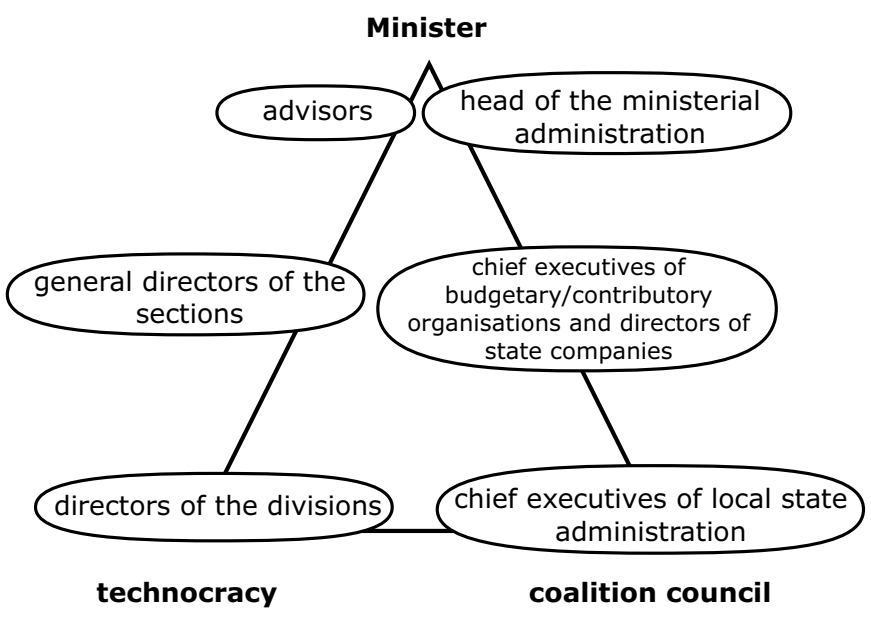

Source: Authors

Due to the lack of relevance of formal institutions none of the actors use the formal legal framework for the differentiation and conceptualisation of political and non-political actors. Minister, state secretary and the head of office are clearly understood to be political actors. With respect to other actors, it is difficult to apply a generalisation.

From the point of view of factors that are the key for self-identification as well as the identification by others, we pinpointed the three main ones.

The first factor is the method of nomination, meaning not the formal recruitment process, but who contacted the individual and with what purpose. A number of interviewees found a more important difference between coalition and personal patronage than between the personal patronage and technocratic decision-making. Coalition nominees are seen as more "politicised" since they are not chosen directly by the minister, and the question of responsive competence can quite often be completely ignored. For example, with regard to the ambassadors a long-term middle manager said: "When choosing the ambassadors there is no difference if the minister comes from within the system or from the outside - because this is done by the government or even coalition, but not the minister."

The second factor is socialisation, where even an individual coming from an external environment behaves in a certain manner creating his personal connections and relations. If his personal values and the culture of work is consistent with the culture of the administration of the given department, and if he successfully 
adapts to this environment, and especially if he displays professional and technical competence in the manner appreciated by the department, the level of his perceived politicisation can be severely weakened. However, the more his role is directly linked with the minister, party and their political activity - for example a spokesperson - the smaller this chance becomes. At the same time there is also an institute of "absorption", where the parties can "absorb" an existing employee in his position, and this employee can still be viewed as apolitical but with an added official political identity.

The third factor is sustainability. The real test of identity is what happens after the change of government. Relatively sharp breaks between Mečiar and Dzurinda, Dzurinda and Fico or Fico and Radičová together with high degree of change in the senior positions lead to the observation that if an individual survives the change of government, his/her political identity withers regardless of how he/she was originally appointed to the position. This was best described by a former advisor to numerous ministers: "A person who experienced numerous ministers in the office in the same position becomes a part of the system."

The third finding of our research is related to differences between de-iure and de-facto rules on senior management selection in the Slovak state agencies. We have found that there are some discrepancies between a de-iure and a de-facto approach in this area:

- Formal and informal rules are not always the same.

- Although the acts provide a dichotomy and distinguish only between minister and government as decision-makers in appointing the senior management level of the state agencies, the real world works with a trichotomy. It means that many of the senior managers at the state agencies are de facto selected by the coalition council/representatives of political parties rather than the government.

\section{Conclusion}

The research conducted on politico-administrative relations in the Slovak state agencies enables us to define "the Slovak model" in this area based on the features of the system that persist or do not change on a larger scale with the change of the governments and the formal rules. In other words, both political representatives and legal acts regulating politico-administrative relations have changed several

4 The research did not focus on other V4 countries (the Czech Republic, Poland, Hungary) and we did not compare our research findings with the situation in these countries. In fact, in the given three countries, there is a small number of scholars focusing on the politico-administrative relations in the public sector and we did not succeed in finding sufficient amount of the data or conclusions for serious comparison with the Slovak case. Therefore we cannot conclude if Slovakia is an exception in the region (outlier), or, on the contrary, is a typical example in the CEE. 
times over the past two decades, but according to our findings the real practice has changed much less.

Our research proved structural/de-iure politicisation in the selection of the senior management level of the state agencies in Slovakia, as most of the positions are being decided by politicians. Specifically, in 2011, 146 out of the 163 senior positions we examined were appointed de iure politically. The picture has changed only somewhat over the last 20 years though there was a slight increase in the non-political positions in 2000s. However, only 52 out of the 146 positions were appointed by a collective political body whereas 94 were appointed by an individual minister.

Switching to the de-facto manner of appointments, we showed that real decision-makers on concrete position are not necessarily the same as defined by law, and the decisions are made not only by ministers or government but also by the coalition council. From the interviews we can conclude that the personal decisionmaking about senior management-level positions at the central government level, including state agencies, is divided into three actors:

- minister or state secretary (including possible influences of his party or other in-groups on his decision-making);

- coalitional decision-making, where the positions are allocated to individual parties that are able to make decisions partially or absolutely independently from the minister;

- long-term stability and mostly technocratic personnel decision-making, where the particular position is not filled only de iure, but also de facto on a basis of an apolitical approach, in which neither the minister nor the political parties interfere.

The personal decision of the minister and the state secretary of the ministry mainly concerns the head of the ministerial administration and the minister's advisors, and to a certain degree also the directors general of the sections and CEOs of subordinated organisations (mostly budgetary and contributory organisations). Coalition-based appointments are related mainly to the statutory positions in local state administration and high executive positions in important organisations controlled by the ministry, mainly in the largest companies and key agencies. The rest is what we call "technocratic" appointments.

When we look at differences between de-iure and de-facto, there are discrepancies. Not only are the formal and informal rules not always the same, but even though the acts provide a dichotomy and distinguish only between minister or government as decision-makers in appointing the senior management level of the state agencies, the real world works with a trichotomy. It means that many of the senior managers at the state agencies are de facto selected by the coalition council/representatives of political parties rather than government. 
We therefore suggest not to treat "politicisation" of agency management as a single, "black-box" concept according to which agency managements (and other senior civil servants) are either political or not as the implications of politicisation vary depending on the type of politicisation. We recommend to work with a trichotomy rather than a dichotomy of political selection processes and distinguish personal nominations of the responsible minister from party nominations based on coalition agreements. The selection mechanism, incentive structure and robustness of actual accountability mechanisms differs more between these two types of politicisations than between the ministerial and formally "non-political" appointment.

\section{References}

Aberbach, J. D., R. D. Putnam and B. A. Rockman. 1981. Bureaucrats and Politicians in Western Democracies. Cambridge, Mass.: Harvard University Press.

Bearfield, M. 2009. “What Is Patronage? A Critical Reexamination.” Public Administration Review 69(1), 64-76.

Beblavý, M. 2009. "Europeanization and Bureaucratic Autonomy in the New Member States: A Case Study of the Agricultural Paying Agency in Slovakia.” Public Administration 87(4), 923-937.

Beblavý, M. 2002. "Understanding the Waves of Agentification and the Governance Problems they have Raised." OECD Journal of Budgeting 1, 121-139.

Gill, D. 2002. "Making Sense of the Zoo: From Agencification To Principled Choice of Government Organisational Forms." (Unpublished draft manuscript, OECD, Paris).

Gregory, R. 2004. "Dire Expectations but Subtle Transformations? Politicization and the New Zealand Public Service." In B. G. Peters and J. Pierre (eds). Politicization of the Civil Service in Comparative Perspective. London : Routledge, pp. 159-179.

Huber, J. and C. Shipan. 2002. Deliberate Discretion? The Institutional Foundations of Bureaucratic Autonomy. Cambridge: Cambridge University Press.

Kaufman, H. 1956. "Emerging Conflicts in the Doctrine of American Public Administration." American Political Science Review 50(4), 1057-1073.

Kopecky, P., M. Spirova and G. Scherlis. 2011. "Beyond the Cartel Party? Party Patronage and the Nature of Parties in New Democracies." Paper prepared for the Joint IPSA/ECPR conference, Sao Paulo, Brazil, 16-19 February 2011.

Malíková, L. 2006. "Relations between Politicians and Civil Servants in Slovakia: Contextual Factors." European Review of Public Law 18(4), 1365-1385. 
Meyer-Sahling, J. H. 2004. "Civil Service Reform in Post-Communist Europe: The Bumpy Road to Depoliticisation." West European Politics 27(1), 71-103.

Mulgan, R. 1999. "Politicising the Australian Public Service." Research Paper 3/1998-99. Department of the Parliamentary Library.

Ondrušová, D. and M. Beblavý. 2012. "Politically Appointed Positions in Slovak Local State Administration - Changes and Tendencies." Proceedings from the conference "Modern and Current Trends in the Public Sector Research." Brno: Masaryk University.

Page, E. and V. Wright. 1999. Bureaucratic Elites in Western Democracies. Oxford: Oxford University Press.

Peters, B. G. 2010. The Politics of Bureaucracy. $6^{\text {th }}$ edn. White Plains: Longman.

Peters, B. G. and J. Pierre. 2004. "Politicization of the Civil Service: Concepts, Causes, Consequences." In B. G. Peters and J. Pierre (eds). Politicization of the Civil Service in Comparative Perspective. London : Routledge, pp. 1-14.

Randma-Liiv, T. and J. Järvalt. 2011. "Public Personnel Policies and Problems in the New Democracies of Central and Eastern Europe." Journal of Comparative Policy Analysis: Research and Practice 13(1), 35-49.

Rouban, L. 2004. "Politicization of the Civil Service in France: From Structural to Strategic Politicization." In B. G. Peters and J. Pierre (eds). Politicization of the Civil Service in Comparative Perspective. London : Routledge, pp. 81-101.

Svara, J. H. 2001. The Myth of the Dichotomy: Complementarity of Politics and Administration in the Past and Future of Public Administration. Raleigh: North Carolina State University.

Van der Meer, F. M. 2009. "Public Sector Reform in Western Europe and the Rise of the Enabling State: An Approach to Analysis." In R Mathur (ed.). Glimpses of Civil Service Reform. Hyderabad: Icfai Press, 171-195.

Van der Meer, F. M., T. Steen and A. Wille. 2007 "Western European Civil Service Systems: A Comparative Analysis." In J. C. N. Raadschelders, T. A. Toonen and F. M. Van der Meer (eds). Civil Service in the $21^{\text {st }}$ Century: Comparative Perspective. Basingstoke : Palgrave Macmillan, pp. 34-49. 